\title{
Organisational resilience following the Darfield earthquake of 2010
}

Zachary Whitman, Joanne Stevenson, Hlekiwe Kachali, Erica Seville, John Vargo, and Thomas Wilson $^{1}$

Pre-print version of paper published in Disasters. Full reference:

Whitman, Z., Stevenson, J., Kachali, H., Seville, E., Vargo, J. and Wilson, T. (2014), Organisational resilience following the Darfield earthquake of 2010. Disasters, 38: 148-177.

doi: $10.1111 /$ disa.12036

This paper presents the preliminary findings of a study on the resilience and recovery of organisations following the Darfield earthquake in New Zealand on 4 September 2010. Sampling included organisations proximal and distal to the fault trace, organisations located within central business districts, and organisations from seven diverse industry sectors. The research captured information on the challenges to, the impacts on, and the reflections of the organisations in the first months of recovery. Organisations in central business districts and in the hospitality sector were most likely to close while organisations that had perishable stock and livestock were more heavily reliant on critical services. Staff well-being, cash flow, and customer loss were major concerns for organisations across all sectors. For all organisations, the most helpful factors in mitigating the effects of the earthquake to be their relationship with staff, the design and type of buildings, and critical service continuity or swift reinstatement of services.

Keywords: Canterbury, Darfield, disaster, earthquake, organisation, resilience

\section{Introduction}

The Darfield earthquake on 4 September 2010 created significant operational challenges for organisations ${ }^{2}$ in the Canterbury region of New Zealand. Organisations faced disruption to critical infrastructure services, building damage, a decline in staff welfare, and restricted access in many areas, leading to immediate significant impacts and affected recovery efforts in the months following the event. The economic consequences of the earthquake for organisations in the region were of major concern, especially when considered in the broader context of New Zealand's economy, which was still recovering from the global

\footnotetext{
${ }^{1}$ Zachary Whitman is a Doctoral Candidate in the Department of Geological Sciences, University of Canterbury, New Zealand; Joanne Stevenson is a Doctoral Candidate in the Department of Geography, University of Canterbury, New Zealand; Hlekiwe Kachali is a Doctoral Candidate in the Department of Civil and Natural Resources Engineering, University of Canterbury, New Zealand; Erica Seville is the Director of Risk Strategies Research and Consulting, New Zealand; John Vargo is a Senior Research Fellow in the Department of Accounting and Information Systems, University of Canterbury, New Zealand; and Thomas Wilson is a Lecturer in the Department of Geological Sciences, University of Canterbury, New Zealand.

${ }^{2}$ The term 'organisation' includes for-profit businesses, not-for-profit organisations, and governmental bodies with a range of ownership structures and sizes.
} 
financial crisis of 2007-08. Accurate information on the disruption and the effects sustained by organisations was, and remains, highly sought after by the business community, civil defence and emergency managers, government officials, researchers, and other stakeholders, as it is necessary to make informed recovery-related decisions.

The New Zealand Treasury's preliminary loss estimate was NZD 5 billion in total, of which approximately NZD 0.75 billion was attributable to commercial loss (New Zealand Treasury, 2010). However, these estimates were based primarily on the generalised assumption that predominantly organisations in damaged areas suffered negatively, not taking into account a variety of other factors, including changes in organisations' customer bases, spatial or sectoral variability and relationships, or supply chain challenges. In previous circumstances, loss estimates based on physical damage alone represent only a small portion of the potential costs to an organisation (Eguchi et al., 1998; Chang and Falit-Baiamonte, 2002). The recovery of an organisation needs to be considered in the context of a dynamic spatial framework that also acknowledges interdependencies and downstream effects.

Many studies have focused on the resilience and recovery of households after natural disasters, but very few have analysed the effect of earthquakes on organisations (Tierney, 1997; Chang and Falit-Baiamonte, 2002; Rose et al., 2007; Chang, 2010). Studies of organisational recovery (more commonly framed as business recovery) identify factors that may influence the level of impact sustained by organisations in a disaster; however, further research is required to provide a better understanding of these potential relationships. Organisations are part of local communities and essential community functions on a day-to-day basis. Importantly, organisations also are critical during the response and recovery periods after a disaster (Brunsdon and Dalziell, 2005). Consequently, it is essential for organisations to be resilient post disaster to ensure their survival and to minimise disruption to societal routines.

By cataloguing the organisational impacts following natural hazards, organisations may better prepare for and mitigate these risks, thus decreasing the overall effect of the event. Generalised impact summaries can obscure many spatial and sector-level consequences owing to the variety of organisational structures and types. Analysing the effects of earthquakes on organisations from a spatial and sectoral perspective is a necessary step in improving practicable mitigation techniques that will improve loss estimates, better inform policy decisions, and increase overall organisational and community resilience.

This paper presents the results of a survey of 376 Canterbury-based organisations following the Darfield earthquake. It assesses the network, physical, and spatial effects of the event and the subsequent aftershocks on a variety of industry sectors and locations throughout the region. The sectors sampled for the study include: agriculture; building suppliers; critical infrastructure organisations (lifelines); fast-moving consumer goods (FMCG); hospitality; information and communication technology (ICT); and trucking. The location samples 
included the Christchurch Central Business District (CBD), the Kaiapoi CBD, and the rural areas proximal to the epicentre, occupied by farming and rural non-farming organisations primarily. The direct and indirect effects of the earthquake are contrasted with organisational and network challenges post disaster to pinpoint the most disruptive factors. Organisations were sampled between November 2010 and early February 2011. Data on the immediate organisational challenges produced by the earthquake help to identify the importance of geographic and network effects and to predicate the importance of the structural integrity of the built environment.

In the months following the sampling, Canterbury was affected by highly damaging aftershocks: on 22 February 2011 ( $\mathrm{M}_{\mathrm{w}}$ (Moment Magnitude) 6.3), 13 June 2011 ( $\mathrm{M}_{\mathrm{w}} 5.8$ and 6.4), and 23 December 2011 ( $\mathrm{M}_{\mathrm{w}} 5.8$ and 6.0). The February event caused the most significant damage to the built, physical, and social environments of the city. All three incidents, though, led to significant disruption. The research on the effects of the Darfield earthquake proved valuable in informing recovery efforts following these aftershocks. This is one of the few studies to gather information on the organisational impacts of the Darfield earthquake without the confounding effects of subsequent significant aftershocks. It is a useful record of the challenges organisations were confronting when the first aftershock occurred on 22 February 2011.

\section{Setting and hazards}

The $\mathrm{M}_{\mathrm{w}}$ 7.1 Darfield earthquake along the Greendale Fault produced an East-West trending surface rupture at least 28-kilometres-long through low relief farmland 40 kilometres west of Christchurch (GeoNet and EQC, 2010; Quigley et al., 2011). The Greendale Fault was unknown prior to the event and is among several other East-West trending strike-slip-dominated faults that are located in the Canterbury Plains. Similar faults in the area, such as the Porter's Pass Fault, accommodate a portion of the transpressional plate boundary motion between the Australasian and Pacific plates and have the potential to generate similar earthquakes. These faults present a significant and poorly understood hazard that requires further research (Pettinga et al., 2001).

While the fault rupture occurred within a relatively compacted system—-the Burnham formation gravels capped by Lismore series soils (Brown soils) — much of Christchurch is built on soft, uncompacted (Kaiapoi or Tai Tapu) soils—Recent and Recent Gley Soils, respectively—which act to amplify the effects of ground shaking and are susceptible to liquefaction. Earthquake intensities, derived from 'Felt Reports', as high as Modified Mercalli Intensity (MMI) 8 were reported in Darfield, Hornby (10 kilometres west of Christchurch), and Lyttleton (11 kilometres southeast of Christchurch). Shaking intensities in the Christchurch CBD following the earthquake ranged from MMI 3 to MMI 8, with a peak ground acceleration (PGA) value of approximately 0.25g (GeoNet, 2011). The highest PGA value of 1.26g was recorded five kilometres from the epicentre, but earthquake intensities proximal to the epicentre showed similar levels to those recorded in the Christchurch CBD, Darfield, and Kaiapoi (GeoNet, 2011). Medial and distal organisations primarily experienced effects related to strong ground motion and liquefaction. Organisations proximal to the fault trace 
were affected not only by strong ground motion and liquefaction, but also by damage to roads, which suffered several metres of lateral offset, changes to the water table, and, along the surface expression, one metre or more of vertical offset (Quigley et al., 2011).

The majority of the damage to structures reported in Christchurch and areas proximal to the epicentre were consistent with an MMI 8-level event, and the earthquake produced ground motions that approached or exceeded Christchurch city building design levels (Ingham and Griffith, 2010; Tonkin and Taylor Limited, 2010). Unreinforced masonry (URM) buildings in Christchurch were most affected by strong ground motion. In total, 21 per cent of URM buildings in Christchurch were red-tagged (deemed unsafe to enter), the majority of which were located on arterial city lines or within the CBD (Ingham and Griffith, 2010). Many of these buildings were composed of two storeys, situated in a row, and leased to organisations (Ingham and Griffith, 2010).

Liquefaction presented the most widespread hazard to the city of Christchurch and the surrounding communities. Prior to this earthquake, Environment Canterbury (ECAN) ${ }^{3}$ estimated that approximately 50 per cent of Christchurch's urbanised area had high liquefaction potential (ECAN and Beca, 2004). During this event, liquefaction caused sand boils, lateral spreading, differential settling, and ground deformation that damaged the road network and other critical infrastructure, as well as building structures and farmland (Almond et al., 2010; Green and Cubrinovski, 2010). There was significant liquefaction in the township of Kaiapoi and the eastern suburbs, which created large amounts of lateral spreading, causing structural damage to the CBD and built infrastructure (Cooper, Carter, and Fenwick, 2011). Some 60 kilometres of the road network in the Christchurch area suffered significant damage (Eidinger, Tang, and O’Rourke, 2010). Liquefaction was also very disruptive for buried utilities such as communication and power (cables), sewerage, and water mains (Eidinger, Tang, and O’Rourke, 2010).

Christchurch's main power distributor reported that more than 166,000 customers were without power electricity at some point on 4 September, although that figure declined to slightly more than 15,000 by the end of the day (Eidinger, Tang, and O’Rourke, 2010). The sharp restoration curve was due in part to the fact that the damage to the electrical network was limited to conductors within the transmission and distribution lines. Several telecommunication cell sites lost power owing to electricity disruptions outlasting backup battery power, requiring diesel generators for continued operation. Restoration of water and wastewater services was slower. Around 10 per cent of Christchurch city and 50 per cent of Kaiapoi were without wastewater for several days following the earthquake. Similarly, 15-20 per cent of Christchurch was without water immediately after the event, but less than five per cent was still without water by the end of the week (Gordon, 2010).

\footnotetext{
${ }^{3}$ See http://ecan.govt.nz/pages/home.aspx.
} 


\section{Organisational experiences post disaster}

Within the domain of organisational disaster studies, there are relatively few impact assessments that have analysed the effects of earthquakes on organisations (Dahlhamer and Tierney, 1996; Webb, Tierney, and Dahlhamer, 1999; Alesch et al., 2001; Chang and Falit-Baiamonte, 2002; Webb, Tierney, and Dahlhamer, 2002; Forsyth and Johnston, 2005; Wasileski, Rodriguez, and Diaz, 2011). Organisational impacts fall into several broad categories, including: direct physical damage to organisational property; indirect damage or losses caused by operational problems; critical service interruptions; closure (business interruption); staff attrition; and relocation costs (Tierney, 1997). Indirect losses related to disasters emerge throughout the recovery period. Comerio (2006), for instance, states that organisational downtime required to plan, finance, and complete repairs, temporary relocation costs, and the need for additional human resources to facilitate recovery work are a real and quantifiable cost of earthquakes. Several studies have also documented the major financial ramifications of critical service infrastructure (lifelines) disruptions, which cause businesses to shut down or operate less efficiently (Kroll et al., 1991; Alesch et al., 1993; Tierney and Nigg, 1995; Webb, Tierney, and Dahlhamer, 1999).

Research gauging the impacts of disasters on organisations has also investigated which factors contribute to an organisation's vulnerability to direct and indirect losses. Organisation size has been implicated as an important predictor of organisational vulnerability in a number of studies (Audretsch, 1991; Alesch and Holly, 1996; Dahlhamer and Tierney, 1996; Alesch et al., 2001; Persson, 2004; Zhang, Lindell, and Prater, 2009), with smaller organisations experiencing greater failure rates. Small-to-medium-size enterprises (SMEs) tend to have limited capital reserves on which to draw following a disaster, and therefore are more reliant on alternative measures to maintain operations if revenue streams are disrupted (Haynes et al., 1999; Alesch et al., 2001; Webb, Tierney, and Dahlhamer, 2002). The age of an organisation also is a potential liability post disaster; as with SMEs, younger organisations frequently have limited capital reserves (Audretsch, 1991; Persson, 2004), fewer assets, and smaller networks from which to access resources.

Chang and Falit-Baiamonte (2002) and Zhang, Lindell, and Prater (2009) suggest that disaster impacts and rates of organisational survival after an event are distributed unevenly across industry sectors. Organisations that employ advanced technology or that are 'capital intensive' (that is, they require large amounts of capital resources to operate) are less likely to fail (Doms, Dunne, and Roberts, 1995). In addition, the average level of educational attainment among a firm's staff members is positively correlated to survivability (Persson, 2004). Consequently, sectors that are more capital intensive and require specialised expertise may demonstrate higher survivability post-earthquake. Similarly, sectors that rely on discretionary spending or smaller local markets can be more vulnerable to the effects of an event. Kroll et al. (1991) found that single location retail, trades such as finance and real estate, and service organisations in the cities of Santa Cruz and Oakland (California, 
United States) experienced proportionally greater losses and had more difficulty recovering from the Loma Prieta earthquake of 1989 than other types of organisations.

There is evidence to suggest that certain sectors value approaches to hazard mitigation planning strategies differently. Stephenson et al. (2010) discovered that planning strategies, such as dedicated emergency management personnel and the development of emergency management plans, were more likely to exist in the health and community sector than in the other sectors sampled. This may be due in part to the necessity of the healthcare industry to follow high reliability organisational practices such as emergency management planning (Pronovost et al., 2006).

Organisational location also has been implicated in the effects experienced by organisations. Chang and FalitBaiamonte (2002) found that organisations in CBDs tended to experience more neighbourhood-related problems, including diminished parking, transportation disruption during reconstruction, and issues related to the negative perception of the business district. Businesses situated in heavily damaged areas, especially if they depended greatly on a local customer base, suffered more than others (Alesch and Holly, 1996; Alesch et al., 2001; Wasileski, Rodriguez, and Diaz, 2011). SMEs are especially vulnerable in urban areas because they are more likely to operate from a single location, lease as opposed to rent, and occupy URM buildings that are vulnerable to earthquake damage, owing to the lower rental costs of older building stock (Alesch et al., 2001; Dahlhamer and D’Souza, 1995). Larger organisations are more likely to have multiple sites, which act to distribute risk, lowering the potential for a single natural disaster to disrupt all operations.

Organisational attributes that mitigate the effects of disasters and allow organisations to adjust to possibly damaging changes post disaster can be broadly referred to as an organisation's resilience. These attributes incorporate elements of planning and adaptive capacity (Stephenson, 2010; Vargo and Seville, 2011), facilitating responsive actions during and following a crisis (Woods and Wreathall, 2008). An organisation's ability to adapt to a changing environment is widely accepted in the literature as a critical reason for growth and success (De Geus, 1988; Huston and Sakkab, 2006). Adaptation also is linked to an organisations' ability to mitigate the impacts of a disaster (Grabowski and Roberts, 1997; Vargo and Seville, 2011).

While planning strategies may be developed prior to a disaster, business owners are more likely to prioritise employee life-safety and fail to address business continuity operations, such as the development of recovery plans or business relocation preparations (Webb, Tierney, and Dahlhamer, 2002). Furthermore, disaster experience does not necessarily boost the development of organisational planning strategies. In the case of the magnitude 7.2 earthquake in the Fiordland region of New Zealand in 2003, less than one-half of the sampled businesses in Manapouri and Te Anau implemented preventative measures following the event (Forsyth, Johnston, and the Institute of Geological and Nuclear Sciences Limited, 2005). These SMEs were less likely than residents to stockpile emergency consumables and secure furniture or other heavy items-actions that 
have been identified as effective in reducing damage and shortening the period of interruption to the operations of organisations.

Some limited evidence exists in the organisational resilience literature to suggest that certain organisation types are more adaptable post disaster. Rural organisations and those in the primary sectors maintain a strong focus on their adaptive capacity, demonstrating high use of family, informal, and social networks to operate following natural disasters (Smith and Krannich, 2001; Rhodes, Willis, and Smith, 2003). The same is true for rural family-run organisations, which have been shown to be highly affected by changes in social capital and to have a tight coupling to the health of the local community (Besser, Recker, and Agnitsch, 2008; Danes et al., 2009; Brewton et al., 2010). Farming organisations, the majority of which include family members, often are exposed to the threat of decreased resilience as the natural hazard negatively affects both their family and organisational systems, both of which may become overwhelmed during crises (Danes et al., 2009).

Furthermore, family and organisational resources frequently are shared. In the US, Winter and Fitzgerald (1993) found that the practice of 'bootstrapping', or the transfer of family resources to the organisation, occurred in nearly one-half of family-owned organisations during normal operations. It is important to note, however, that, while natural hazards generally have been studied in relation to farming organisations, the effects of earthquakes largely are omitted from the literature and thus very poorly understood.

\section{Methods}

The results presented in this paper comprise the first part of a two-year study to track the ongoing recovery of Canterbury organisations following the Darfield earthquake of 2010. A survey was designed to capture the initial impacts, the disruptions and challenges to organisations, and information on the organisational attributes, relationships, and strategies that may have helped to mitigate the effects of the earthquake. It procured mainly quantitative data, and was supplemented by a limited number of qualitative questions to enhance understanding of organisations' experience of the earthquake. In general, the type of data obtained was subjective; the responses reflect only the subjective evaluations of the participants. Fewer survey items collected objective data, such as changes in revenue and in the total number of employees. While subjective data have inherent interpretational limitations, they are of value in making initial estimates, whereas many objective data are not available in the short term. However, objective data will be collected in subsequent data captures and comparisons will be possible with the subjective initial estimates.

Questions were designed to determine the effect of the earthquake on an organisation by isolating the overall change observed following the event. The limitation in this methodology is that the changes identified are relative, and do not establish the state of the organisation prior to the event. Hence the conclusions reached from these data do not resolve the variable of the pre-existing condition of the organisation, which is an inherent limitation of sampling organisations post disaster. 
The survey included a shortened form of the complete Benchmark Resilience Tool developed by the Resilient Organisations Research Programme (McManus, 2008; Stephenson, 2010; Stephenson et al., 2010). The complete Benchmark Resilience Tool was composed of 13 indicators that were formed using several items per indicator, whereas the shortened version used only one item per each of the 13 indicators. The latter was intended to measure an organisation's resilience 'thumbprint' without significantly adding to the length of the survey. These 'thumbprint' results will be compared to results obtained by the complete Benchmark Resilience Tool in subsequent surveys.

The collection of the survey data was approached using a modified multi-media version of the 'total design method' described by Dillman (1978), comprising an initial mailing followed by a series of mailings and telephone calls. Our modified version consisted of an initial mailing or a physical drop-off followed by a telephone call. When reached by telephone the potential respondent was offered response options that included: returning the survey booklet by mail; completing the survey over the telephone; completing the survey via an online survey engine; or completing the survey in soft-copy and e-mailing it back.

Data collection took place between 17 November 2010 and 18 February 2011. Organisations were given five weeks to respond to questionnaires if they preferred not to answer by telephone. Respondents could also request a meeting with the researcher to fill out the questionnaire in person. The use of these multiple data collection methods was necessary to accommodate organisations that, in many cases, were too busy to complete the survey over the telephone or to return it by mail and organisations that had relocated and not received the original paper copy of the survey.

\section{Sample}

Organisations were selected using a stratified random sampling technique based on industry sector and geographic location. Industry sectors included those that are a part of the Canterbury Regional Economic Development Strategy (CREDS), such as the agricultural and ICT sectors, those that provide services critical in response and recovery efforts, and those that capture discretionary and non-discretionary spending of consumers. The sample was largely composed of small-to-medium-sized for-profit organisations; however organisational structure did not serve as a selection criterion.

Organisations were also selected by area. Two sample groups were chosen based on their location relative to the fault scarp in the rural Selwyn District, and hereafter are classified as 'rural farm' and 'rural non-farm'. Organisations were also selected within the CBDs in Christchurch, Canterbury's largest city and economic centre, and Kaiapoi, a smaller town situated 20 kilometres north of Christchurch, which was majorly affected by liquefaction and lateral spreading.

The final locations and sectors selected for sampling were: 
- building suppliers (wholesale and retail);

- critical infrastructure organisations (lifelines);

- FMCG, including dairies/petrol stations, food producers, and supermarkets;

- hospitality (specifically bars, cafes, and restaurants);

- ICT;

- rural farm;

- rural non-farm (located proximal to the fault trace);

- trucking;

- Christchurch CBD; and

- Kaiapoi CBD.

This list is not a comprehensive representation of the economy of Canterbury. The breadth of the sample, however, means that the data extracted from this survey could be extrapolated to the wider economy of Canterbury owing to sector inter-dependencies. ICT and rural farm are vital high-growth sectors. The trucking sector represents a crucial link in the supply chains of many other industry sectors. FMCG and hospitality represent non-discretionary and discretionary consumer spending, respectively. Lifelines and building suppliers represent sectors that are critical to the response and recovery of Canterbury organisations. The rural non-farm and Christchurch and Kaiapoi CBDs were included because of their significance to a community's day-to-day activities, and the possibility of analysing the spatial and network recovery factors of a large number of organisations concentrated in one physical area.

\section{Results and discussion}

Descriptive statistics

In total, 869 organisations were contacted about the 'Organisational Resilience and Recovery’ survey. We received 376 responses, representing a response rate of 42 per cent. Figure 1 shows the locations of the organisations that took part in the survey. 


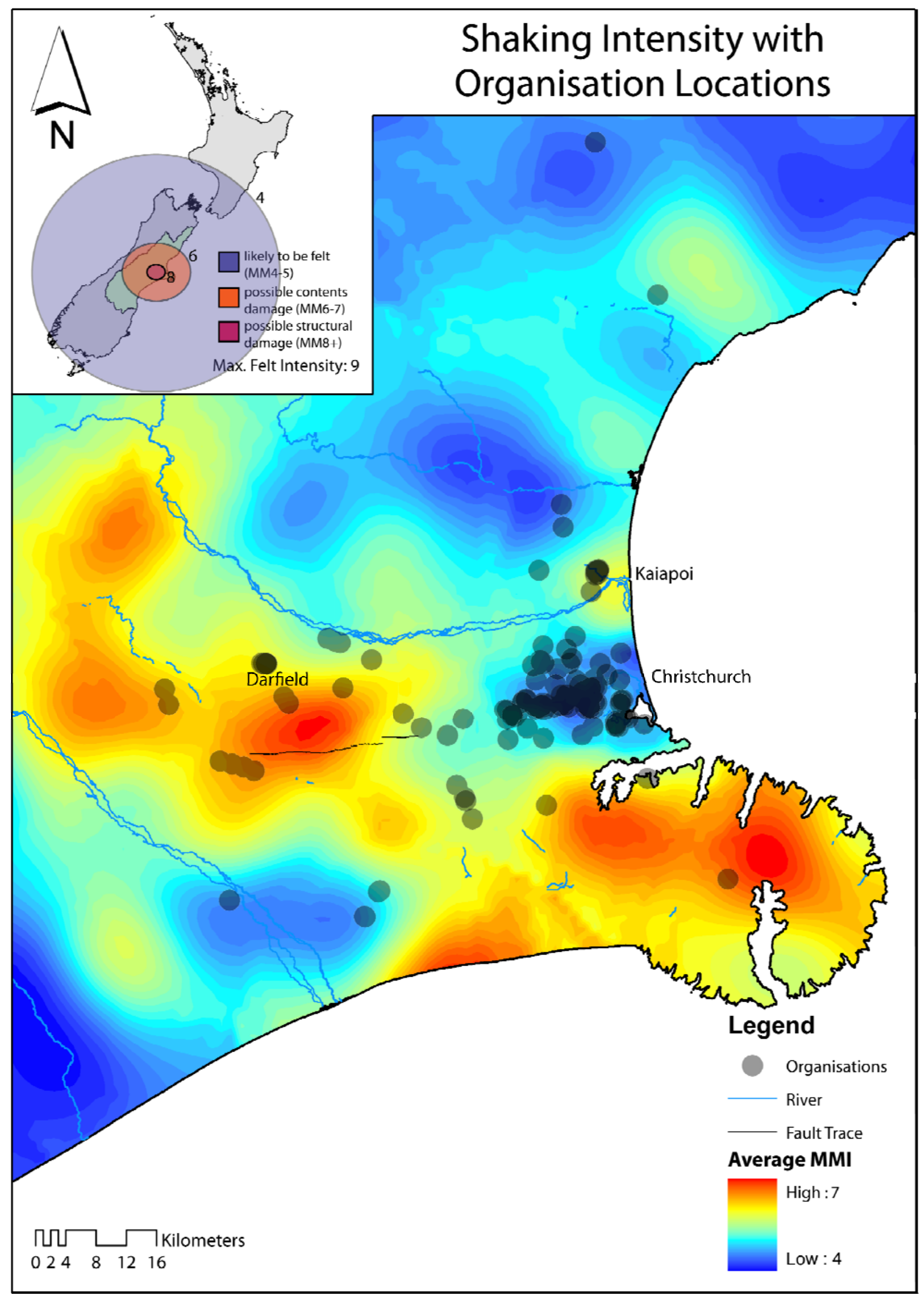


Figure 1. Location of sampled organisations in relation to MMI intensities derived from GeoNet felt reports Note: the isoseismal projection in the inset is derived from GeoNet (2011). In areas of low population densities, the intensity estimation is controlled by fewer data points while highly agglomerated areas are populated by many data points. Therefore, the overall degree of shaking is represented with a large margin of error. The direction of greatest shaking occurred along the same direction of the surface fault line, and was also reported up the coast from Christchurch and at some locations on the Banks Peninsula. Although the MMI scale goes as high as MM12, one should note that the felt report questionnaire can only determine intensities up to MM8. Intensities above MM9 usually are determined by engineers who inspect damaged structures in some detail.

Data Source: GeoNet, 2011.

The sectors with the highest and the lowest response rates were the ICT sector (55 per cent) and rural farm (21 per cent), respectively. The low response rate in the rural farm sample is believed to be in part an artefact of the sampling methodology, as not all organisations received follow-up calls because of an inability to collect contact details for these organisations. ${ }^{4}$ Table 1 contains a complete sectoral breakdown of basic organisational information.

Table 1. Sample characteristics and per cent affected broken down by sector

\begin{tabular}{|c|c|c|c|c|c|c|c|c|c|c|c|c|c|c|}
\hline \multirow{3}{*}{ Sector } & \multirow{2}{*}{\multicolumn{2}{|c|}{$\begin{array}{l}\text { Response } \\
\text { rate }\end{array}$}} & \multicolumn{6}{|c|}{ Number of employees } & \multirow{2}{*}{\multicolumn{2}{|c|}{$\begin{array}{c}\text { Years } \\
\text { operating }\end{array}$}} & \multirow{2}{*}{\multicolumn{2}{|c|}{$\begin{array}{c}\text { Years operating at } \\
\text { location }\end{array}$}} & \multirow{3}{*}{$\begin{array}{c}\text { Property } \\
\text { owner }\end{array}$} & \multirow{3}{*}{$\begin{array}{c}\begin{array}{r}\text { Affec } \\
\text { ted }\end{array} \\
\%\end{array}$} \\
\hline & & & \multicolumn{2}{|c|}{ Full-time } & \multicolumn{2}{|c|}{ Part-time } & \multicolumn{2}{|c|}{ Temporary } & & & & & & \\
\hline & $N$ & $\%$ & $\begin{array}{c}\text { Me } \\
\text { an }\end{array}$ & $\begin{array}{c}\text { Medi } \\
\text { an }\end{array}$ & $\begin{array}{c}\text { Me } \\
\text { an }\end{array}$ & $\begin{array}{c}\text { Medi } \\
\text { an }\end{array}$ & $\begin{array}{c}\text { Me } \\
\text { an }\end{array}$ & $\begin{array}{c}\text { Medi } \\
\text { an }\end{array}$ & $\begin{array}{c}\text { Me } \\
\text { an }\end{array}$ & $\begin{array}{c}\text { Medi } \\
\text { an }\end{array}$ & Mean & Median & & \\
\hline $\mathrm{ICT}$ & 55 & 55 & 18 & 6 & 2 & 2 & 3 & 1 & 15 & 11 & 9 & 5 & 24 & 56 \\
\hline Hospitality & 32 & 32 & 9 & 5 & 18 & 7 & 1 & 1 & 13 & 10 & 11 & 7 & 9 & 94 \\
\hline Trucking & 38 & 38 & 31 & 10 & 9 & 2 & 1 & 1 & 33 & 24 & 17 & 13 & 45 & 71 \\
\hline Lifelines & 24 & 55 & 233 & 112 & 41 & 13 & 192 & 4 & 80 & 100 & 48 & 28 & 54 & 92 \\
\hline FMCG & 42 & 49 & 154 & 75 & 63 & 52 & 4 & 0 & 38 & 24 & 20 & 11 & 24 & 88 \\
\hline $\begin{array}{l}\text { Buildings } \\
\text { suppliers }\end{array}$ & 30 & 31 & 11 & 7 & 2 & 1 & 1 & 1 & 25 & 20 & 11 & 8 & 40 & 70 \\
\hline $\begin{array}{l}\text { Rural non- } \\
\text { farm }\end{array}$ & 42 & 27 & 9 & 2 & 3 & 2 & 11 & 2 & 25 & 11 & 17 & 8 & 57 & 88 \\
\hline Rural farm & 30 & 21 & 35 & 2 & 2 & 2 & 1 & 1 & 34 & 28 & 26 & 19 & 93 & 67 \\
\hline $\begin{array}{l}\text { Christchurch } \\
\text { CBD }\end{array}$ & 33 & 45 & 15 & 3 & 29 & 3 & 2 & 2 & 35 & 30 & 16 & 12 & 6 & 90 \\
\hline $\begin{array}{l}\text { Kaiapoi } \\
\text { CBD }\end{array}$ & 40 & 31 & 5 & 3 & 4 & 2 & 1 & 1 & 35 & 20 & 21 & 13 & 13 & 90 \\
\hline Total & $\begin{array}{c}36 \\
6\end{array}$ & 36 & 46 & 5 & 17 & 3 & 26 & 1 & 31 & 19 & 18 & 10 & 35 & 80 \\
\hline
\end{tabular}

The distribution of organisation size in this study generally reflects the size of organisations throughout Canterbury and the rest of New Zealand. Most of the organisations in New Zealand are classified as small businesses (Welch, 2008). A large proportion (77 per cent) of organisations sampled had fewer than 20 fulltime employees, with a majority (51 per cent) of the total sample employing fewer than five full-time staff members. Organisations with greater than 100 full-time employees comprised 10 per cent of the sample. Table 1 contains a complete breakdown of sector attributes.

\footnotetext{
${ }^{4}$ This was observed most significantly for farming organisations, as many of their contact details are private residences with unlisted telephone numbers.
} 
Organisations were asked to report on how long they have been in operation and the duration of their operations in their current location. The majority of organisations (67 per cent) have been operational for 10 or more years. Respondents from lifelines organisations have operated, on average, longer than any other sector (80 years), while organisations in the hospitality sector reported the lowest average operational age (13 years). Similarly, lifelines organisations have a longer average duration of operations from their current location than any other sector (48 years), while organisations in the ICT sector have occupied their current location for the shortest period of time on average (9 years).

Duration of operation was positively correlated to the mean and median number of full-time employees ( $r=0.81, p=0.005$ and $r=0.72, p=0.005$, respectively) and the mean number of temporary staff ( $r=0.64$, $p=0.005)$. The older, more established organisations tended to be the largest employers. Organisations that rent the property from which they operate represented a majority (65 per cent) of the sampled population. Only in two sectors-rural farm and rural non-farm—did a majority of organisations own the property from which they operated.

Organisations that rent their premises do not have control over the building structure, which in turn could affect their capacity to plan for their recovery. In one case, for instance, a building owner and organisation renting premises in the Christchurch CBD disagreed on how long the building should have remained closed after it was deemed safe for use. The organisation occupying the building was more focused on reopening after it had been inspected whereas the building owner did not regard reopening as an urgent priority, highlighting the conflicting priorities that may exist between building owners and tenants.

Following the collection of basic organisational information (summarised in Table 1), organisations were asked whether they had been 'affected' by the Darfield earthquake. Overall, 80 per cent of all organisations responding to the survey said that they were affected by the event. If organisations felt that they had been completely 'unaffected' by the Darfield earthquake, they were instructed to move to the end of the survey to complete the resilience 'thumbprint' section. Thus, all impact and mitigation data reported here are from organisations that stated that they had been affected by the earthquake.

\section{Impacts}

Organisations were asked 'how disruptive were the following on your ability to do business?' and provided with a list of potentially disruptive factors. The degree to which a factor was disruptive to an organisation was quantified using a four-point Likert scale. The organisations were asked to rank earthquake-related disruption on a scale of 'not at all disruptive' (assigned a score of '0') to ‘very disruptive' (assigned a score of '3').

These scores were averaged across each sector, and then divided by the maximum score of ' 3 ' to calculate the severity of the disruption item for each sector. The factor score ranged from $0-100$ per cent -0 per cent 
indicating that all organisations found the factor to be 'not at all disruptive' and 100 per cent indicating that all organisations found the factor to be 'very disruptive'. Table 2 shows the results.

Table 2. Average organisational disruption scores broken down by item and sector Note: disruption scores of more than 50 per cent (moderate to very disruptive) are in bold.

\begin{tabular}{|c|c|c|c|c|c|c|c|c|c|c|c|}
\hline Sector & 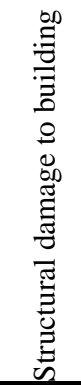 & 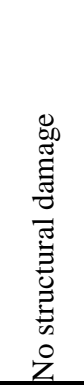 & 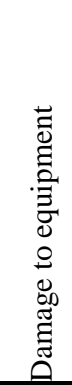 & 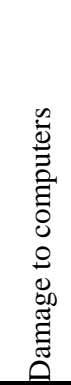 & 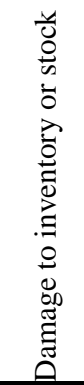 & 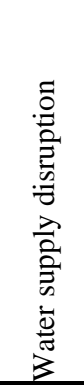 & 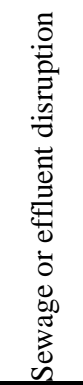 & 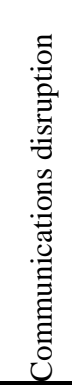 & 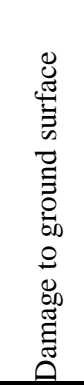 & 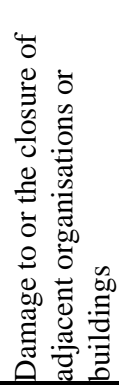 & 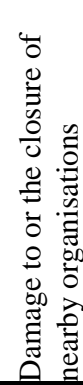 \\
\hline ICT & $17 \%$ & $29 \%$ & $17 \%$ & $13 \%$ & $12 \%$ & $24 \%$ & $11 \%$ & $40 \%$ & $10 \%$ & $30 \%$ & $32 \%$ \\
\hline Hospitality & $16 \%$ & $22 \%$ & $22 \%$ & $5 \%$ & $46 \%$ & $36 \%$ & $15 \%$ & $16 \%$ & $2 \%$ & $51 \%$ & $52 \%$ \\
\hline Trucking & $15 \%$ & $15 \%$ & $16 \%$ & $7 \%$ & $26 \%$ & $11 \%$ & $7 \%$ & $23 \%$ & $10 \%$ & $6 \%$ & $12 \%$ \\
\hline Lifelines & $23 \%$ & $29 \%$ & $24 \%$ & $15 \%$ & $16 \%$ & $24 \%$ & $18 \%$ & $18 \%$ & $18 \%$ & $22 \%$ & $15 \%$ \\
\hline FMCG & $21 \%$ & $41 \%$ & $26 \%$ & $10 \%$ & $70 \%$ & $28 \%$ & $18 \%$ & $30 \%$ & $11 \%$ & $18 \%$ & $31 \%$ \\
\hline $\begin{array}{l}\text { Building } \\
\text { suppliers }\end{array}$ & $25 \%$ & $22 \%$ & $12 \%$ & $8 \%$ & $35 \%$ & $6 \%$ & $0 \%$ & $13 \%$ & $11 \%$ & $13 \%$ & $13 \%$ \\
\hline $\begin{array}{l}\text { Rural non- } \\
\text { farm }\end{array}$ & $23 \%$ & $42 \%$ & $34 \%$ & $20 \%$ & $42 \%$ & $28 \%$ & $10 \%$ & $37 \%$ & $8 \%$ & $24 \%$ & $25 \%$ \\
\hline Rural farm & $38 \%$ & $47 \%$ & $47 \%$ & $28 \%$ & $28 \%$ & $58 \%$ & $27 \%$ & $38 \%$ & $22 \%$ & $18 \%$ & $17 \%$ \\
\hline $\begin{array}{l}\text { Christchurch } \\
\text { CBD }\end{array}$ & $31 \%$ & $31 \%$ & $15 \%$ & $9 \%$ & $16 \%$ & $17 \%$ & $8 \%$ & $33 \%$ & $6 \%$ & $62 \%$ & $64 \%$ \\
\hline Kaiapoi CBD & $46 \%$ & $26 \%$ & $25 \%$ & $13 \%$ & $35 \%$ & $77 \%$ & $69 \%$ & $53 \%$ & $53 \%$ & $78 \%$ & $83 \%$ \\
\hline All groups & $25 \%$ & $31 \%$ & $24 \%$ & $13 \%$ & $35 \%$ & $32 \%$ & $19 \%$ & $31 \%$ & $16 \%$ & $34 \%$ & $37 \%$ \\
\hline
\end{tabular}

No single factor proved to be consistently disruptive to all of the sectors sampled. Organisations in the Kaiapoi CBD reported higher overall disruption across all items. The most disruptive item for Kaiapoi organisations proved to be 'damage to or the closure of nearby organisations'. This was also the most disruptive item for organisations in the Christchurch CBD and the third most disruptive item for the hospitality sector. Organisations in the Kaiapoi and Christchurch CBDs and the hospitality sector also found 'unable to access site' very disruptive to their ability to do business. These factors were cited as being more disruptive than 'structural damage to building'. Interestingly, 'structural damage to building' did not prove to be the most disruptive item for any sector sampled, although certain sectors indicated experiencing more structural damage than others, as can be seen in Table 2 .

Although it was not specifically asked about in the survey, organisations in the Christchurch and Kaiapoi CBDs and some of the organisations in the hospitality sector were located inside cordoned-off areas. As evidenced in the CBDs, organisations noted that, even when they did not suffer any structural damage, they were forced to close because of their proximity to unsafe buildings or because of their location in areas that were officially cordoned-off. This was not a significant issue for the majority of organisations outside of the 
CBD, highlighting the differences in risks assumed by organisations located within CBDs (Stevenson et al., 2011). In general, CBD areas have a higher proportion of older, historic buildings that are more vulnerable to earthquake damage (Chang and Falit-Baiamonte, 2002). Locating an organisation within a CBD offers the benefit of increased access to customers, infrastructure, and other organisations, while increasing exposure to damage to neighbouring structures and the likelihood of being located within a cordoned-off area. Workers and shoppers may also be put off by the perceived risk of multi-storey building collapse in a future earthquake.

Organisations in the CBDs found that damage to or the closure of nearby organisations was disruptive. They did not find relationships with their neighbours to be as helpful in mitigating the effects of the disaster. Conversely, rural farm and rural non-farm organisations were not as affected by the closure of or damage to nearby organisations. Yet they found their relationships with neighbours to be very helpful in mitigating the effects of the earthquake. Owing to the limitations of this study, these relationships were not examined in detail and further work is planned as part of the two-year ongoing study to understand the importance of network relationships and sectoral differences post disaster.

The level of lifelines service interruption varied within sectors according to location. The major electricity distributor prioritised densely populated areas for the restoration of service, thereby slightly extending the period of power outage in the rural farm and non-farm sectors. Farming organisations especially demonstrate a significant difference in need for critical services and lifelines. For instance, dairy cattle require regular milking, otherwise the health of the livestock is compromised and the quality of milk is negatively affected. Livestock represent a significant investment for many farming organisations and therefore they are exposed to loss during extended periods of lifelines service interruptions. The latter also proved very disruptive for organisations within the FMCG sector, as organisations with perishable items were particularly sensitive to electricity and water outages. The FMCG and the farming sectors are more dependent on rapid restoration of service as they have the potential to lose stock because of critical service disruption.

Organisations were also asked to report whether their organisation was relocated as a result of the earthquake. At the time of the survey, a large majority (92 per cent) of affected organisations had not relocated. Twenty per cent of organisations in the Kaiapoi CBD relocated, representing one-third of all sampled organisations that relocated. This higher concentration of relocations in Kaiapoi might be because of the higher percentage of buildings in the Kaiapoi CBD that were damaged during the Darfield earthquake as compared to the Christchurch CBD.

Comparatively, only 10 per cent of affected organisations sampled from the Christchurch CBD relocated. Approximately 16 per cent of organisations in the ICT sector relocated. The majority of organisations in the 
ICT sector were forced to relocate owing to non-structural damage or restricted access to their site. Other sectors that had at least one organisation relocate were FMCG, rural farm, rural non-farm, and trucking.

The reasons for not relocating might vary across sectors. For example, no organisations in the hospitality sector relocated despite reporting high levels of damage. Barriers to relocation in the hospitality sector might include the nature of the equipment used, the customer base, and health and safety regulations. In contrast, the ability of ICT organisations to relocate may indicate that they have more flexibility in this respect. The primary reason of the respondents for the majority of organisations relocating was building damage. However, three CBD organisations and one ICT organisation cited waiting for building assessments and an inability to access their building as reasons for relocating. The ICT organisation, for instance, reported that it relocated because its 'office [was] within the cordon due to damage to adjacent buildings'. Two organisations, one FMCG and one ICT, reported damage to non-structural elements as a reason for relocation.

Organisations that indicated structural damage as highly disruptive were significantly more likely to relocate. The disruptive effect of structural damage to organisations was highest in the Kaiapoi CBD sample, which, as mentioned, had the highest rate of relocation among the sample groups. Organisations in the ICT sector differed from this trend, however: the majority of relocations were not related to structural damage, but rather to site access and non-structural damage. Overall, the majority of organisations did not experience significant structural damage, which is part of the reason why relatively few organisations relocated. It is not clear from these results, though, whether more organisations were planning on relocating and had not yet done so at the time of sampling.

\section{Closure}

Of those organisations that were affected by the Darfield earthquake, the majority (63 per cent) were forced to close for a period of time. Table 3 contains a sectoral breakdown of the data.

Table 3. Proportion of affected organisations that closed, total sample that closed, and the length of closure per sector

\begin{tabular}{|c|c|c|c|c|c|c|}
\hline \multirow{2}{*}{ Sector } & \multirow[b]{2}{*}{$N$} & \multicolumn{2}{|l|}{ Closed organisations } & \multicolumn{2}{|c|}{$\begin{array}{l}\text { Length of average } \\
\text { closure (days) }\end{array}$} & \multirow{2}{*}{$\begin{array}{l}\text { Length of median } \\
\text { closure (days) }\end{array}$} \\
\hline & & Percentage closed (affected) & $\begin{array}{c}\text { closed (total } \\
\text { sample) }\end{array}$ & Mean & $\begin{array}{l}\text { Standard } \\
\text { deviation }\end{array}$ & \\
\hline ICT & 17 & 55 & 31 & 3 & 2 & 2 \\
\hline Hospitality & 28 & 93 & 88 & 8 & 5 & 7 \\
\hline Trucking & 8 & 30 & 21 & 11 & 24 & 2 \\
\hline Lifelines & 9 & 41 & 38 & 4 & 2 & 3 \\
\hline FMCG & 29 & 78 & 69 & 2 & 4 & 1 \\
\hline Building suppliers & 11 & 50 & 37 & 3 & 5 & 2 \\
\hline Rural non-farm & 23 & 62 & 55 & 5 & 6 & 4 \\
\hline Rural farm & 1 & 5 & 3 & 2 & 0 & 2 \\
\hline
\end{tabular}




\begin{tabular}{|l|ccc|c|c|c|} 
Christchurch CBD & 29 & 97 & 88 & 9 & 8 & 7 \\
Kaiapoi CBD & 31 & 86 & 78 & 11 & 15 & 7 \\
All groups & 186 & 64 & 51 & 7 & 10 & 4 \\
\hline
\end{tabular}

Of those organisations that reported closing for a period of time, the average length of the closure was seven days. Organisations that were still closed at the time of sampling were excluded from the mean and median closure calculation. One organisation indicated that closure would be for 12 months while another has restricted its operating hours to only afternoons owing to a decline in business activity. Three organisations stated at the time of sampling that closure was indefinite. Organisations from the Kaiapoi CBD and the trucking sector were closed for an average of 11 days, which was the longest period of time for all sectors. Many organisations included in the FMCG sample reported closing at some point for a period of approximately one to three days. Overall, the hospitality, lifelines, and rural farm sectors were the only ones that did not include at least one outlier or extreme value and were consequently the only sectors where the mean closure time was not right-skewed. The trucking sector specifically had one organisation that reported closing for a period of 70 days, while the remainder of the sample was tightly grouped with a median closure length of two days.

The sample groups with the highest proportion of closures were in the Kaiapoi CBD (78 per cent), Christchurch CBD (88 per cent), and hospitality sector (88 per cent). The sample groups with the lowest proportion of closures were rural farm (3 per cent) and trucking (21 per cent). The differences in closure proportions may be generally attributable to the location of the organisation (in terms of exposure to damage and cordons), but the nature of the business also plays a part. For example, farming organisations do not close in the traditional sense, while most hospitality organisations are unable to operate without electricity or water.

The survey also asked organisations about the reasons for closure following the Darfield earthquake or the subsequent aftershocks (between 17 November 2010 and 18 February 2011). More than one-half (58 per cent) of affected organisations were forced to close because they were 'waiting for their building to be structurally assessed'. This was the most commonly cited reason for the closure of organisations within the following sectors: Christchurch CBD (80 per cent); ICT (92 per cent); and Kaiapoi CBD (64 per cent). The second most common reason (50 per cent of respondents) was the need to 'clear up damage to the interior'. The sectors to cite this reason for closure most frequently were FMCG (77 per cent) and rural non-farm (79 per cent). The majority of organisations in the FMCG sample also cited 'stock loss or damage' as a reason for closure.

Table 4 shows correlations between different reasons for closure and highlights the strength and directionality between them. The most commonly cited reason for closure, 'building waiting to be structurally assessed', was negatively correlated to the second most commonly cited reason for closure, 'needed to clear up damage to the interior' $(r=-0.73, p<0.05)$. Reasons for closure that were related to structural damage were positively 
correlated with one another. Non-structural reasons for closure were negatively correlated to structural damage. Organisations' reasons for closure following the earthquake can thus be placed in one of two discrete categories: closure due to structural damage; closure due to non-structural damage. Organisations that reported not being able to 'obtain replacement supplies or materials' also reported not being able to 'deliver supplies/services to customers'. This shows the effect of disruption to the supply chain. 
Table 4. Correlations of reasons for closure

Note: bold values are significant to $p<0.05$.

\begin{tabular}{|c|c|c|c|c|c|c|c|c|c|c|c|c|}
\hline & 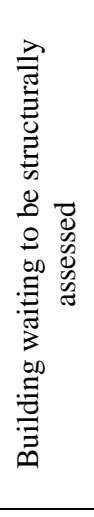 & 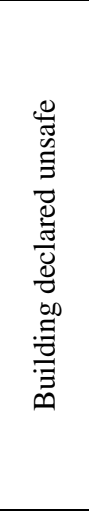 & 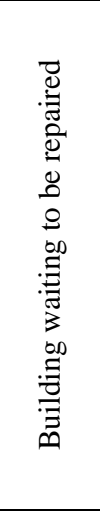 & 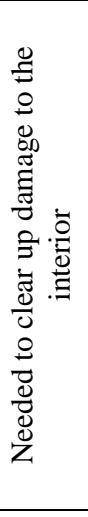 & 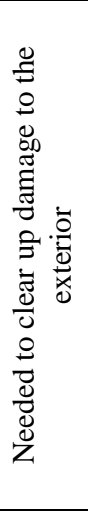 & 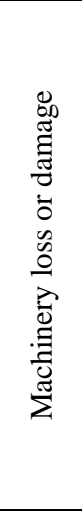 & 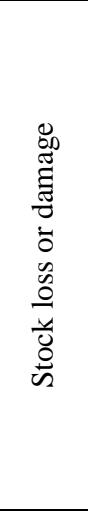 & 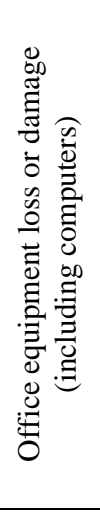 & 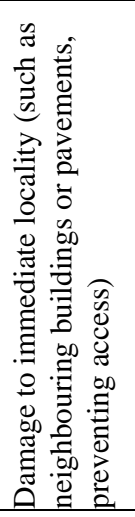 & 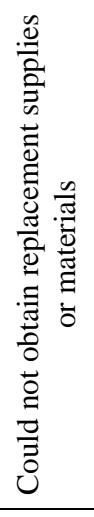 & 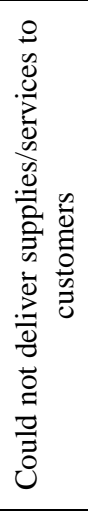 & 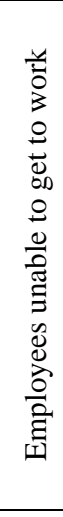 \\
\hline $\begin{array}{l}\text { Building waiting to be structurally } \\
\text { assessed }\end{array}$ & 1.00 & & & & & & & & & & & \\
\hline Building declared unsafe & & 1.00 & & & & & & & & & & \\
\hline Building waiting to be repaired & & 0.64 & 1.00 & & & & & & & & & \\
\hline $\begin{array}{l}\text { Needed to clear up damage to the } \\
\text { interior }\end{array}$ & -0.78 & -0.70 & & 1.00 & & & & & & & & \\
\hline $\begin{array}{l}\text { Needed to clear up damage to the } \\
\text { exterior }\end{array}$ & -0.81 & & & & 1.00 & & & & & & & \\
\hline Machinery loss or damage & -0.79 & & & 0.73 & 0.93 & 1.00 & & & & & & \\
\hline Stock loss or damage & & & & & & & 1.00 & & & & & \\
\hline $\begin{array}{l}\text { Office equipment loss or damage } \\
\text { (including computers) }\end{array}$ & -0.75 & & -0.66 & & 0.84 & 0.87 & & 1.00 & & & & \\
\hline $\begin{array}{l}\text { Damage to immediate locality (such } \\
\text { as neighbouring buildings or } \\
\text { pavements, preventing access) }\end{array}$ & & & & & & & -0.70 & & 1.00 & & & \\
\hline $\begin{array}{l}\text { Could not obtain replacement supplies } \\
\text { or materials }\end{array}$ & & & & & & & 0.67 & & -0.62 & 1.00 & & \\
\hline $\begin{array}{l}\text { Could not deliver supplies/services to } \\
\text { customers }\end{array}$ & & & & & & & 0.60 & -0.65 & -0.84 & 0.70 & 1.00 & \\
\hline Employees unable to get to work & & & & & 0.76 & 0.79 & -0.61 & 0.77 & 0.73 & & -0.76 & 1.00 \\
\hline
\end{tabular}




\section{Network effects}

The majority of organisations within the Kaiapoi and Christchurch CBDs as well as the hospitality sector experienced changes to their customer base. In the Kaiapoi and Christchurch CBD samples, 31 and 48 per cent of organisations, respectively, reported 'substantial' decreases in customer numbers whereas 23 and 34 per cent, respectively, reported 'moderate' falls. In the building suppliers sector, 29 per cent of affected organisations experienced substantial reductions in their customer base, whereas 57 per cent reported no change. The lifelines sector saw a substantial rise in the customer base, largely attributable to the organisations that deal with waste management having an increased workload because of debris removal.

Organisations were asked whether their revenue increased, decreased, or did not change following the Darfield earthquake. At the time of sampling, the majority (61.5 per cent) of organisations had observed no change to their revenue, as seen in Table 3. Of those reporting a change in revenue, the effect was largely negative. The Christchurch CBD, the Kaiapoi CBD, and the hospitality sector had the greatest number of organisations reporting revenue loss. Overall, the organisations reporting the greatest percentage drop in revenue are in the CBDs and the rural non-farm sector. The FMCG and lifelines sectors reported modest gains in revenue. Table 5 presents a complete sectoral breakdown of the changes in organisational revenue .

Table 5. Summary of revenue changes per sector

\begin{tabular}{|l|ccc|ccc|}
\hline \multirow{2}{*}{ Sector } & \multicolumn{3}{|c|}{ Revenue decreases } & \multicolumn{3}{c|}{ Revenue increases } \\
& $N$ & Mean decrease & Standard deviation & $\boldsymbol{N}$ & Mean increase & Standard deviation \\
\hline ICT & 6 & $30 \%$ & $13 \%$ & 2 & $20 \%$ & $14 \%$ \\
Hospitality & 18 & $28 \%$ & $12 \%$ & 5 & $13 \%$ & $4 \%$ \\
Trucking & 9 & $25 \%$ & $15 \%$ & 4 & $22 \%$ & $7 \%$ \\
Lifelines & 1 & $35 \%$ & $0 \%$ & 3 & $23 \%$ & $23 \%$ \\
FMCG & 5 & $7 \%$ & $8 \%$ & 5 & $19 \%$ & $12 \%$ \\
Buildings suppliers & 11 & $30 \%$ & $20 \%$ & 2 & $30 \%$ & $14 \%$ \\
Rural non-farm & 14 & $40 \%$ & $27 \%$ & 3 & $75 \%$ & $109 \%$ \\
Rural farm & 1 & $2 \%$ & $0 \%$ & 0 & $0 \%$ & $0 \%$ \\
Christchurch CBD & 21 & $37 \%$ & $22 \%$ & 1 & $15 \%$ & $0 \%$ \\
Kaiapoi CBD & 22 & $40 \%$ & $31 \%$ & 3 & $18 \%$ & $4 \%$ \\
All groups & 108 & $33 \%$ & $23 \%$ & 28 & $23 \%$ & $33 \%$ \\
\hline
\end{tabular}

Organisations were asked to forecast how long they thought the earthquake would continue to affect their revenue. Thirty-eight per cent stated that the impacts on their revenue had ceased by 30 September 2010. The second most commonly reported expected duration for revenue change (19 per cent of organisations) was more than one year from 4 September 2010. In contrast, only three per cent of responding organisations 
indicated that changes in revenue would persist for approximately one year, which was the least commonly expected duration for revenue change.

In general, more organisations hired staff than made personnel redundant in the five months following the Darfield earthquake. In total, sampled organisations affected by the event made 13 full time, 17 part-time, and 4 temporary employees redundant, whereas 103 full-time, 146 part-time, and 73 temporary employees were hired. Organisations were not asked to specify whether redundancies and hires were due to the earthquake, but many organisations that reported redundancies identified the cause as the normal business cycle. The FMCG and lifelines sectors took on the largest number of additional staff, which is most probably because of the heavy demands placed on these sectors post-earthquake. For example, waste management organisations in the lifelines sector saw an increase in their customer base. These organisations hired several temporary employees to service the rise in demand. Throughout the lifelines sector, temporary and contract workers represented the majority of hires following the earthquake, which is most probably attributable to the demand to make a large number of repairs quickly.

However, the building suppliers sector had not yet seen the economic boom that it had been expecting after the earthquake. Only 37 per cent of organisations in the sector closed for any period of time. Yet a majority of affected buildings suppliers reported a loss in revenue following the earthquake, with an average decrease of 30 per cent. Organisations in this sector also cited forecasting demand and waiting for customers to get insurance settlements as their biggest challenges post earthquake.

The majority of affected organisations (67 per cent) reported using cash flow to finance recovery. In the ICT and building suppliers sectors, more than 90 per cent of organisations identified cash flow as a means of financing their recovery. Insurance was the second most common source with which to finance recovery, most commonly cited by the FMCG, hospitality, and rural farm sectors. Approximately 12 per cent of reporting organisations cited using the Earthquake Support Subsidy (ESS) to finance recovery. The majority of affected organisations held insurance policies for organisational interruption, property and buildings, organisational assets, motor vehicles, public liability, and commodities. Certain sectors, such as FMCG, ICT, lifelines, rural farm, and trucking, relied almost entirely on cash flow, savings, and insurance to finance their recovery.

Sample groups that relied on a variety of alternative means to finance recovery, such as borrowing money from family or friends, bank loans, and credit cards, were the Christchurch and Kaiapoi CBDs and the building suppliers and hospitality sectors. Significant positive correlations exist between sample groups that used money borrowed from friends and family and organisations that used credit cards $(r=0.92, p<0.05)$ and bank loans $(r=0.96, p<0.05)$. Respondents that relied on bank loans for recovery financing also showed strong correlations to the use of credit cards $(r=0.91, p<0.05)$. The sample groups that relied on organisational cash flow were unlikely to rely on their savings $(r=-0.83, p<0.05)$ or on their insurance claims $(r=-0.80, p<0.05)$. 


\section{$\underline{\text { Mitigation factors }}$}

Organisations were given a list of 14 potential factors that helped contribute to mitigating disruption to operations. Using a four-point Likert scale ranging from 'not at all helpful' to 'very helpful', these organisations were asked to identify the usefulness of each factor. These factors were then averaged at the sectoral level and divided by the total possible score to ascertain a sector mitigation factor score that ranged from 0-100 per cent ( 0 per cent indicating that all organisations in a sector found the factor to be 'not at all helpful' in mitigating the effects of the earthquake and 100 per cent indicating that all organisations found the factor to be 'very helpful' in doing so).

The factors that organisations found most helpful in mitigating disruption to operations after the Darfield earthquake were (in order of reported helpfulness):

- $\quad$ well-designed and well-built buildings;

- relationship with staff; and

- critical services restored quickly or not interrupted.

The two most important factors for the majority of sectors were either 'well-designed and well-built buildings' or 'relationship with staff'. On average, across all sectors, well-designed and well-built buildings was reported to be the most helpful factor in mitigating disruption. At the sectoral level, though, the FMCG, Kaiapoi CBD, and lifelines samples identified 'relationship with staff' as the most important mitigating factor.

Organisations that used resources other than their organisation's cash flow found available cash or credit to be a helpful factor in mitigating the impact of the earthquake. Rural farm and rural non-farm organisations indicated that their 'relationship with neighbours' was helpful in mitigating the effects of the earthquake, whereas other sectors found this to be less important to their mitigation strategy. Table 6 contains complete sectoral results of the mitigating factors.

Table 6. Sectoral results of the mitigation factor scores per item Note: mitigation factor scores of more than 50 per cent (moderately to very helpful) are in bold. 


\begin{tabular}{|c|c|c|c|c|c|c|c|c|c|c|c|c|c|c|}
\hline & 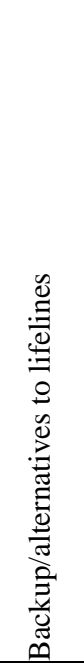 & 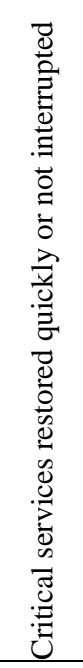 & 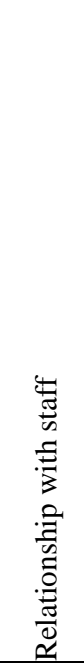 & 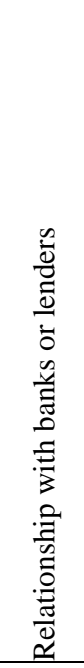 & 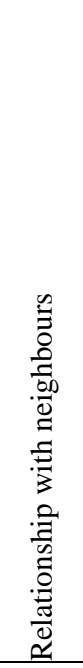 & 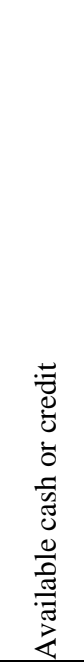 & 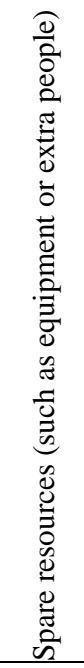 & 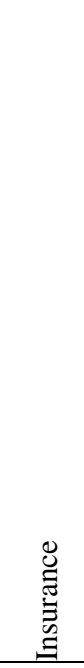 & 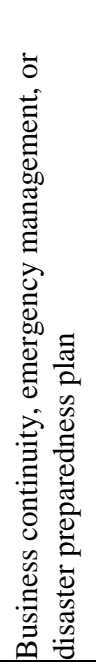 & 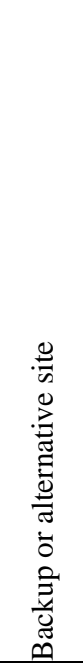 & 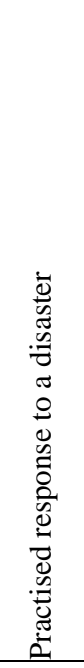 & 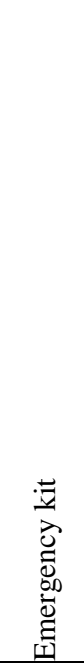 & 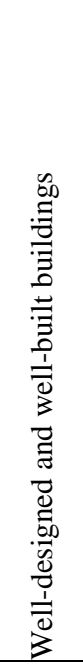 & 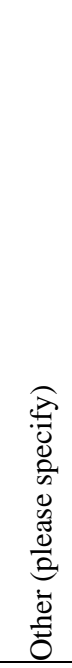 \\
\hline ICT & $24 \%$ & $64 \%$ & $68 \%$ & $21 \%$ & $24 \%$ & $43 \%$ & $18 \%$ & $13 \%$ & $40 \%$ & $29 \%$ & $33 \%$ & $18 \%$ & $71 \%$ & $33 \%$ \\
\hline Hospitality & $17 \%$ & $60 \%$ & $75 \%$ & $51 \%$ & $49 \%$ & $60 \%$ & $27 \%$ & $54 \%$ & $20 \%$ & $8 \%$ & $5 \%$ & $7 \%$ & $81 \%$ & $44 \%$ \\
\hline Trucking & $14 \%$ & $52 \%$ & $60 \%$ & $27 \%$ & $24 \%$ & $31 \%$ & $33 \%$ & $36 \%$ & $24 \%$ & $13 \%$ & $19 \%$ & $21 \%$ & $65 \%$ & $29 \%$ \\
\hline Lifelines & $55 \%$ & $76 \%$ & $87 \%$ & $11 \%$ & $22 \%$ & $35 \%$ & $64 \%$ & $33 \%$ & $83 \%$ & $33 \%$ & $79 \%$ & $53 \%$ & $83 \%$ & $\begin{array}{c}100 \\
\%\end{array}$ \\
\hline FMCG & $23 \%$ & $60 \%$ & $82 \%$ & $30 \%$ & $24 \%$ & $43 \%$ & $47 \%$ & $51 \%$ & $61 \%$ & $29 \%$ & $52 \%$ & $32 \%$ & $75 \%$ & $40 \%$ \\
\hline Building suppliers & $18 \%$ & $47 \%$ & $63 \%$ & $32 \%$ & $19 \%$ & $35 \%$ & $11 \%$ & $26 \%$ & $18 \%$ & $9 \%$ & $16 \%$ & $16 \%$ & $77 \%$ & $0 \%$ \\
\hline Rural non-farm & $41 \%$ & $69 \%$ & $67 \%$ & $41 \%$ & $67 \%$ & $52 \%$ & $43 \%$ & $51 \%$ & $32 \%$ & $9 \%$ & $29 \%$ & $32 \%$ & $78 \%$ & $\begin{array}{l}52 \\
\%\end{array}$ \\
\hline Rural farm & $52 \%$ & $67 \%$ & $42 \%$ & $32 \%$ & $63 \%$ & $53 \%$ & $55 \%$ & $65 \%$ & $35 \%$ & $17 \%$ & $28 \%$ & $52 \%$ & $85 \%$ & $10 \%$ \\
\hline Christchurch CBD & $18 \%$ & $47 \%$ & $69 \%$ & $32 \%$ & $45 \%$ & $55 \%$ & $26 \%$ & $40 \%$ & $37 \%$ & $27 \%$ & $24 \%$ & $21 \%$ & $69 \%$ & $\begin{array}{l}67 \\
\%\end{array}$ \\
\hline Kaiapoi CBD & $41 \%$ & $49 \%$ & $72 \%$ & $52 \%$ & $50 \%$ & $60 \%$ & $39 \%$ & $47 \%$ & $39 \%$ & $34 \%$ & $24 \%$ & $17 \%$ & $59 \%$ & $0 \%$ \\
\hline All groups & $30 \%$ & $59 \%$ & $69 \%$ & $34 \%$ & $40 \%$ & $47 \%$ & $36 \%$ & $42 \%$ & $39 \%$ & $21 \%$ & $31 \%$ & $26 \%$ & $74 \%$ & $32 \%$ \\
\hline
\end{tabular}

Strong correlations exist between certain mitigating factors. For example, organisations that found 'practised response to a disaster' helpful in mitigating organisational disruption also found 'business continuity, emergency management, or disaster preparedness plan' helpful $(r=0.97, p<0.05)$. In addition, organisations that found 'business continuity, emergency management, or disaster preparedness plan' helpful showed a large positive correlation with the number of full-time employees. Table 7 provides details of all significant correlations $(p<0.05)$.

Table 7. Correlations of mitigating factor scores analysed at the sector level

Note: values in bold are significant to $\mathrm{p}<0.05$. 


\begin{tabular}{|c|c|c|c|c|c|c|c|c|c|c|c|c|c|c|c|c|}
\hline & 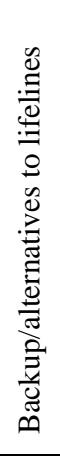 & 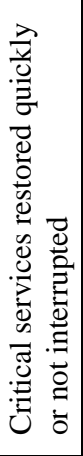 & 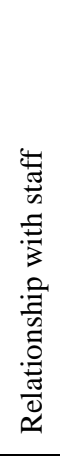 & 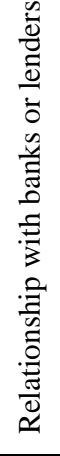 & 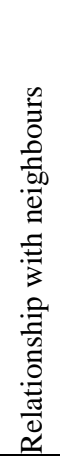 & 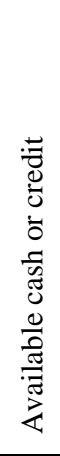 & 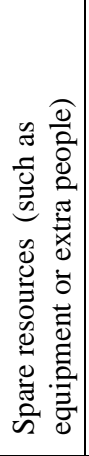 & 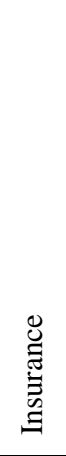 & 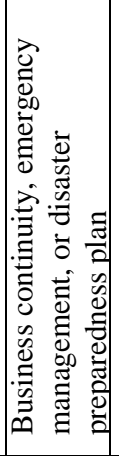 & 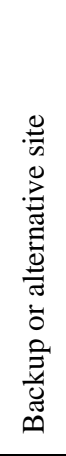 & 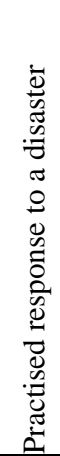 & 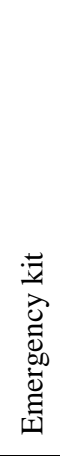 & 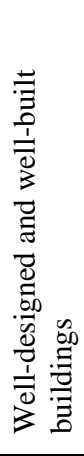 & 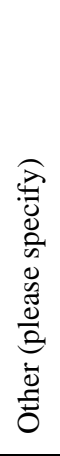 & 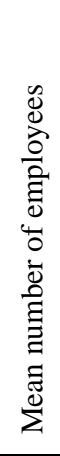 & 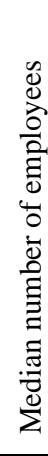 \\
\hline $\begin{array}{l}\text { Backup/alternatives to } \\
\text { water, sewerage, } \\
\text { electricity, } \\
\text { communications }\end{array}$ & $\begin{array}{c}1.0 \\
0\end{array}$ & & & & & & & & & & & & & & & \\
\hline $\begin{array}{l}\text { Water, sewerage, } \\
\text { electricity, } \\
\text { communications were } \\
\text { restored quickly or not } \\
\text { interrupted }\end{array}$ & $\begin{array}{c}0.6 \\
8\end{array}$ & $\begin{array}{c}1.0 \\
0\end{array}$ & & & & & & & & & & & & & & \\
\hline Relationship with staff & & & $\begin{array}{c}1.0 \\
0\end{array}$ & & & & & & & & & & & & & \\
\hline $\begin{array}{l}\text { Relationship with banks } \\
\text { or lenders }\end{array}$ & & & & $\begin{array}{c}1.0 \\
0\end{array}$ & & & & & & & & & & & & \\
\hline $\begin{array}{l}\text { Relationship with } \\
\text { neighbours }\end{array}$ & & & & & $\begin{array}{c}1.0 \\
0\end{array}$ & & & & & & & & & & & \\
\hline Available cash or credit & & & & $\begin{array}{c}0.7 \\
9\end{array}$ & $\begin{array}{c}0.8 \\
0\end{array}$ & $\begin{array}{c}1.0 \\
0\end{array}$ & & & & & & & & & & \\
\hline $\begin{array}{l}\text { Spare resources (such as } \\
\text { equipment or extra } \\
\text { people) }\end{array}$ & $\begin{array}{c}0.7 \\
9\end{array}$ & $\begin{array}{c}0.6 \\
8\end{array}$ & & & & & $\begin{array}{c}1.0 \\
0\end{array}$ & & & & & & & & & \\
\hline Insurance & & & & & $\begin{array}{c}0.7 \\
4\end{array}$ & & & $\begin{array}{c}1.0 \\
0\end{array}$ & & & & & & & & \\
\hline $\begin{array}{l}\text { Business continuity, } \\
\text { emergency management, } \\
\text { or disaster preparedness } \\
\text { plan }\end{array}$ & & & & & & & $\begin{array}{c}0.7 \\
2\end{array}$ & & 1.00 & & & & & & & \\
\hline Backup or alternative site & & & & & & & & & 0.75 & $\begin{array}{c}1.0 \\
0\end{array}$ & & & & & & \\
\hline $\begin{array}{l}\text { Practised response to a } \\
\text { disaster }\end{array}$ & & $\begin{array}{c}0.6 \\
5\end{array}$ & & $\begin{array}{c}- \\
0.7 \\
0\end{array}$ & & & $\begin{array}{c}0.7 \\
0\end{array}$ & & 0.97 & $\begin{array}{c}0.6 \\
4\end{array}$ & $\begin{array}{c}1.0 \\
0\end{array}$ & & & & & \\
\hline Emergency kit & $\begin{array}{c}0.8 \\
0\end{array}$ & $\begin{array}{c}0.7 \\
1\end{array}$ & & & & & $\begin{array}{c}0.8 \\
6\end{array}$ & & 0.68 & & $\begin{array}{c}0.7 \\
4\end{array}$ & $\begin{array}{c}1.0 \\
0\end{array}$ & & & & \\
\hline $\begin{array}{l}\text { Well-designed and well- } \\
\text { built buildings }\end{array}$ & & $\begin{array}{c}0.6 \\
7\end{array}$ & & & & & & & & & & & $\begin{array}{c}1.0 \\
0\end{array}$ & & & \\
\hline Other (please specify) & & & & & & & & & 0.65 & & & & & $\begin{array}{c}1.0 \\
0\end{array}$ & & \\
\hline $\begin{array}{l}\text { Mean number of } \\
\text { employees }\end{array}$ & & & & $\begin{array}{c}- \\
0.6 \\
4\end{array}$ & & & $\begin{array}{c}0.6 \\
9\end{array}$ & & 0.91 & & $\begin{array}{c}0.9 \\
3\end{array}$ & $\begin{array}{c}0.6 \\
6\end{array}$ & & & $\begin{array}{c}1.0 \\
0\end{array}$ & \\
\hline
\end{tabular}




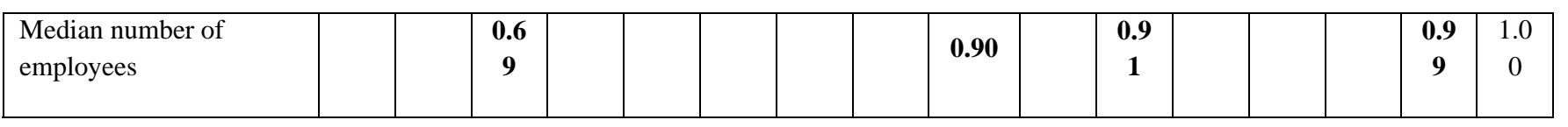

Larger organisations were significantly more likely to have found business continuity plans to be helpful in mitigating organisational disruption. In addition, organisations that had practised responses to disasters indicated that these drills were helpful in mitigating organisational disruption. However, only in the FMCG and lifelines sectors did a majority of affected organisations indicate that 'practised response to a disaster' was moderately to very effective in mitigating the effects of the disaster. These data show that organisations with business continuity, disaster preparedness, or emergency management plans find them useful, and believe them to be more effective when rehearsed. Furthermore, the lifelines sector found the rehearsal of an emergency response plan to be more helpful than the plan itself, indicating that emergency management plans may be of secondary importance to practise and review.

The only sector that found 'relationship with staff' relatively unimportant in mitigating the effects of the earthquake was rural farm. Instead, rural farms identified 'backup/alternatives to water, sewerage, electricity, communications' to be an important factor in mitigating the impacts of the earthquake, as the health of livestock is dependent on these services. Comparatively, the FMCG sector, which was majorly affected by damage to inventory or stock, did not report 'backup/alternatives to water, sewerage, electricity, communications' to be especially important in mitigating the impacts of the earthquake. Organisations in the FMCG sector found the rapid restoration or continuity of critical services to be more important. This is partially related to the fact that the rural communities experienced greater disruption periods as compared to more densely populated areas, and thus were more reliant on alternative utilities for longer periods of time.

Government-support programmes following the Darfield earthquake were made available to organisations. Examples include the Canterbury Business Recovery Trust Fund, Individual Support Payments, the Earthquake Support Subsidy, Rural Support Payments, and tax relief and extension options. There has been substantial uptake of the support subsidy programme by businesses. For instance, the New Zealand Department of Labour found that more than 50 per cent of sampled businesses had received wage subsidies, which totalled NZD 10.6 million in payouts to 2,800 businesses from 4 September to 1 November 2011 (Brownlee, 2011; Labour and Immigration Research Centre, 2011). According to official sources, these subsidies were helpful to the majority of organisations that received the assistance (Labour and Immigration Research Centre, 2011). Furthermore, support helplines, information databases, and business mentors were made available to organisations at no cost (Canterbury Development Corporation and Canterbury Employers' Chamber of Commerce, 2010). 
Organisations were asked about the biggest challenges following the Darfield earthquake, the results of which were grouped by sector. For all sectors, the majority of respondents cited staff well-being as a challenge for operations after the event. All of the other major challenges cited by organisations are broken down by sector in Table 8.

Table 1. Summary of the greatest challenges to each sector following the Darfield earthquake

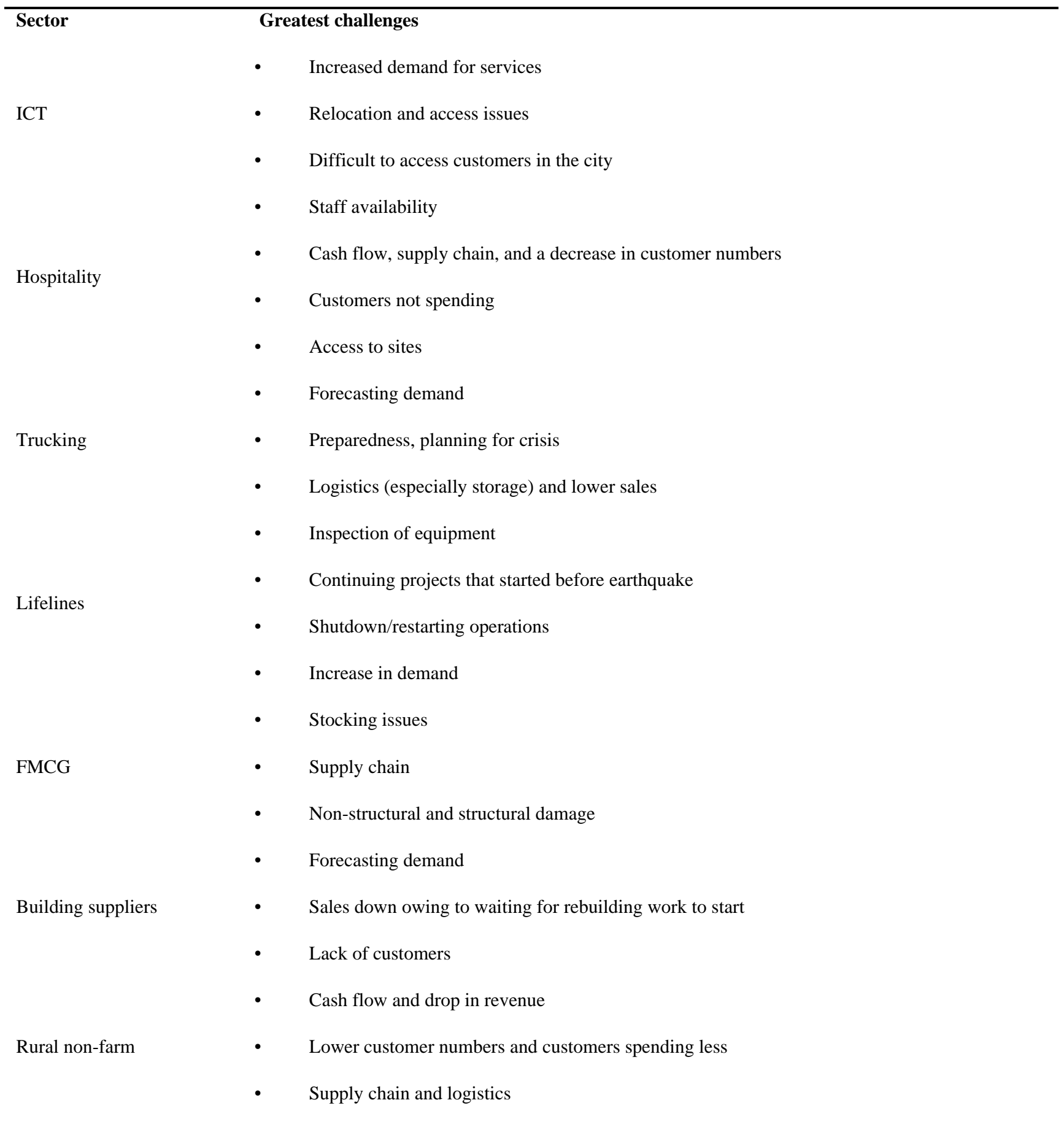




\begin{tabular}{lll}
\hline Rural farm & $\bullet$ & Disruption of lifelines \\
& $\bullet$ & Structural repairs \\
• & Customers believing that Christchurch CBD was closed \\
Christchurch CBD & Accessing site \\
- & Customer spending, cash flow, revenue \\
Kaiapoi CBD & Lack of customers/customers not spending \\
& Relocation \\
& Access to site and structural damage \\
\hline
\end{tabular}

Organisations identified myriad challenges relating to staff management, including: stress and fear in staff; loss of productivity; and diminished focus. In the Kaiapoi CBD, organisations stated that part of the reason for decreased productivity was customers occupying staff while relaying their earthquake experiences. One organisation is quoted as saying that its biggest challenge was: 'the amount of time spent with customers and staff talking and counselling about the effects of the earthquake on them. Some people want to talk about it a lot'. Both the Christchurch and Kaiapoi CBDs identified the public perception of the CBDs as being off-limits and site and road inaccessibility as significant challenges to their organisations even when they were fully operational. Organisations also believed that damage to and cordons around nearby organisations kept potential customers away.

\section{Conclusion}

This study identifies the direct and indirect physical, spatial, and network impacts on organisations following the Darfield earthquake of 4 September 2010. Resilient organisations mitigate them by consistently preparing for and adapting to their hazard-scape. The study catalogues the initial effects of the earthquake across a range of sectors in order to appraise the overall disruption to organisations, to pinpoint the controlling factors based on organisational characteristics, and to contextualise organisational recovery. In addition it lays the foundation for future data captures in the months after an event to understand better organisational resilience.

While the strong ground motion forced a majority of organisations to close owing to some level of direct physical damage, such as liquefaction, non-structural damage, stock loss, and a lack of access, there was a wide variety of disruptive consequences related to the earthquake, and all industry sectors showed unique sensitivities. Many organisations belonging to the same industry sector were affected in similar ways, which in part is due to industry-wide vulnerabilities, such as barriers to relocation or the holding of perishable stock. The resources on which organisations relied to mitigate the effects of the earthquake also demonstrated some sectoral patterns, illustrating the inherent resilience of sectors to the effects of earthquakes. 
The study finds some degree of sector-level resilience to the effects of the Darfield earthquake by identifying the vulnerabilities of affected organisations. For instance, organisations located in CBDs showed high vulnerability to structural damage, damage to neighbouring buildings, inability to access their premises, and public misperception - these results are consistent with the findings of previous analyses from the US (Dahlhamer and D’Souza, 1995; Alesch et al., 2001). Farming organisations were vulnerable to damage to buried infrastructure, fence lines, and operational infrastructure such as dairy sheds. Dairy farming was especially vulnerable to critical service interruptions. The FMCG sector was also highly vulnerable to critical service outages; however, these losses appear to have been offset by increased demand in the days after 4 September 2010. Instead, the primary vulnerability of this industry was predicting and keeping up with demand for certain products while minimising losses because of non-structural damage. The lifelines sector was most vulnerable to physical damage to infrastructure.

Rural organisations, even those close to the fault trace, did not show significantly higher levels of disruption owing to physical damage when compared to organisations in Christchurch and Kaiapoi. This suggests that other processes, such as liquefaction — which was a major contributor to organisational disruption in many parts of Kaiapoi-complicate the pattern of disruption observed. The CBD, FMCG, hospitality, and rural nonfarm sectors were most likely to have been forced to close and for the longest period of time, while farming organisations were least likely to have closed.

At the time of sampling (between two and five months post event), 61.5 per cent of organisations reported no change in their overall revenue. The percentage of organisations reporting changes in revenue was slightly lower than that in the findings of Chang and Falit-Baiamonte (2002); this difference, though, is probably due to the fact that, notably, medium- and long-term loss data were not available at the time of sampling. Organisations that reported the greatest decrease in revenue were from the Christchurch CBD, the Kaiapoi CBD, and the hospitality sector. The FMCG, lifelines, and rural farm sectors reported modest increases. Building supplies organisations largely had not experienced increases in demand for goods/services, which were widely anticipated following the observation of structural damage.

Factors that organisations reported as being most effective in mitigating disruption included well-designed and well-built buildings, relationship with staff, and critical services restored quickly or not interrupted. Organisations showed a large reliance on built infrastructure, highlighting the importance of strong building codes, as well as the use of alternative means of data management, such as cloud computing, as a potential improvement. Organisations also demonstrated a heavy reliance on lifelines services; developing back-up alternatives is another potential area of improvement for a variety of sectors.

All of the earthquake-related impacts were not yet evident at the time of sampling and it is the intention of this research project to follow these organisations for a period of 18-24 months to identify what medium-term 
effects may exist. However, owing to the 22 February and 13 June 2011 earthquakes, which caused significantly greater damage to the Christchurch built and social environments, the research will need to sample affected organisations once again to gather preliminary impact data specific to these new events, while also procuring more in-depth information as part of the study.

The study will seek to understand how an organisation's pre-earthquake characteristics, including its level of resilience, affect its ability to recover and to adapt to new economic and social environments post earthquake. The study will also investigate the unique challenges faced by organisations in CBDs, some of which have been referred to in the preliminary results presented in this paper, as well as the role of business models, networks, and supply chains in recovery.

\section{Acknowledgements}

The authors gratefully acknowledge the funding received from the New Zealand Natural Hazard Research Platform, Ministry for Agriculture and Forestry, Ministry for Civil Defence and Emergency Management, and the University of Canterbury Mason Trust. Thanks are extended to Amy Hall, Christian Ruegg, Hai Sue Kang, Hosai Najib, Lara Hawke, Jonathon Pettigrew, Kathryn Bates, Mark Letham, Rachel McConnell, and Sarah Standring for assisting with telephone interviews. Thanks also to the New Zealand GeoNet project and its sponsors the Earthquake Commission, GNS Science, and Land Information New Zealand, for providing the data/images used in this study, and to the two anonymous peer reviewers for their valuable and supportive comments. Finally, we gratefully acknowledge the time and effort of the respondents who chose to participate in this study. This research is part of the Resilient Organisations research programme, which has initiated a longitudinal study of organisations affected by the Canterbury earthquakes. The results of the programme will be made available on the organisation’s website (http://www.resorgs.org.nz).

\section{Correspondence}

Zachary Whitman, Geological Sciences, University of Canterbury, Private Bag 4800, Christchurch, New Zealand. E-mail: zachary.whitman@pg.canterbury.ac.nz

\section{References}

Alesch, D.J. and J.N. Holly (1996) How to Survive the Next Natural Disaster: Lessons for Small Business from Northridge Victims and Survivors. Paper presented at the 'Pan Pacific Hazards 96 meeting', Vancouver, BC, 29 July-2 August.

Alesch, D.J., C.E. Taylor, A.S. Ghanty, and R.A. Nagy (1993) 'The earthquake hazard and small business'. In K.J. Tierney and J.M. Nigg (eds.) 1993 National Earthquake Conference Monograph 5: Socioeconomic Impacts. Central United States Earthquake Consortium, Memphis, TN. pp. 133-160. 
Alesch, D.J., J.N. Holly, E. Mittler, and R. Nagy (2001) Organizations at Risk: What Happens when Small Businesses and Not-for-Profits Encounter Natural Disasters. Public Entity Risk Institute, Fairfax, VA.

Almond, P. et al. (2010) 'Agricultural land rehabilitation following the 4 September 2010 Canterbury earthquake: a preliminary report'. Bulletin of New Zealand Society of Earthquake Engineering. 43(4). pp. 532-538.

Audretsch, D.B. (1991). 'New-firm survival and the technological regime'. The Review of Economics and Statistics. 73(3). pp. 441-450.

Besser, T.L., N. Recker, and K. Agnitsch (2008) 'The impact of economic shocks on quality of life and social capital in small towns'. Rural Sociology. 73(4). pp. 580-604.

Brewton, K.E., S.M. Danes, K. Stafford, and G.W. Haynes (2010) 'Determinants of rural and urban family firm resilience'. Journal of Family Business Strategy. 1(3). pp. 155-166.

Brownlee, G. (2011) 'Accommodation support for quake-affected'. 18 February. http://www.beehive.govt.nz/release/accommodation-support-quake-affected (accessed on 14 December 2011).

Brunsdon, D. and E. Dalziell (2005) 'Making organisations resilient: understanding the reality of the challenge'. CAE: Resilient Infrastructure - Conference Handbook. pp. 27-34. http://ir.canterbury.ac.nz/bitstream/10092/2814/1/12598223_Resilient_InfrastructureBrunsdon\%20Dalziell.pdf (accessed on 22 October 2013).

Canterbury Development Corporation and Canterbury Employers' Chamber of Commerce (2010) 'Lessons from Recover Canterbury’. http://www.recovercanterbury.co.nz/ (accessed on 2 March 2012).

Chang, S.E. (2010) 'Urban disaster recovery: a measurement framework and its application to the 1995 Kobe earthquake’. Disasters. 34(2). pp. 303-327.

Chang, S.E. and A. Falit-Baiamonte (2002) 'Disaster vulnerability of businesses in the 2001 Nisqually earthquake’. Environmental Hazards. 4(2). pp. 59-71.

Comerio, M.C. (2006) 'Estimating downtime in loss modelling'. Earthquake Spectra. 22(2). pp. 349-365.

Cooper, M., R. Carter, and R. Fenwick (2011) Canterbury Earthquakes Royal Commission Interim Report. Canterbury Earthquakes Royal Commission, Wellington, NZ.

Dahlhamer, J.M. and K.J. Tierney (1996) Winners and Losers: Predicting Business Disaster Recovery Outcomes following the Northridge Earthquake. Disaster Research Center, University of Delaware, Newark, DE.

Dahlhamer, J.M. and M.J. D’Souza (1995) Determinants of Business Disaster Preparedness in Two U.S. Metropolitan Areas. Disaster Research Center, University of Delaware, Newark, DE.

Danes, S.M. et al. (2009) 'Determinants of family business resilience after a natural disaster by gender of business owner’. Journal of Developmental Entrepreneurship. 14(4). pp. 333-354.

De Geus, A.P. (1988) ‘Planning as learning’. Harvard Business Review. 66(2). pp. 70-74.

Dillman, D. (1978) Mail and Telephone Surveys: The Total Design Method. Wiley, New York, NY. 
Doms, M., T. Dunne, and M.J. Roberts (1995) 'The role of technology use in the survival and growth of manufacturing plants'. International Journal of Industrial Organization. 13(4). pp. 523-542.

ECAN (Environment Canterbury) and Beca (Beca Carter Hollings and Ferner Limited) (2004) The Solid Facts on Christchurch Liquefaction. ECAN, Christchurch.

Eguchi, R.T. et al. (1998) 'Direct economic losses in the Northridge earthquake: a three-year post-event perspective'. Earthquake Spectra. 14(2). pp. 245-264.

Eidinger, J., A. Tang, and T. O’Rourke (2010) Technical Council on Lifeline Earthquake Engineering (TCLEE) Report of the 4 September 2010 Mw 7.1 Canterbury (Darfield), New Zealand Earthquake. TCLEE, Reston, VA.

Forsyth, P.J., D.M. Johnston, and the Institute of Geological and Nuclear Sciences Limited (2005) Survey of Te Anau and Manapouri Businesses following the 2003 Fiordland Earthquake. GNS Science, Wellington.

GeoNet (2011) ‘GeoNet - Quake web services’. http://geonet.org.nz/quakes/services (accessed on 22 October 2013).

GeoNet and EQC (Earthquake Commission) (2010) 'Earthquake report - Sep 42010 at 4:35 am (NZST)'. http://geonet.org.nz/earthquake/quakes/3366146g.html (accessed on 29 March 2011).

Gordon, M. (2010) Canterbury Earthquake 4 September 2010 Lifeline Utilities Overview. Canterbury Engineering Lifelines Group, Christchurch.

Grabowski, M. and K. Roberts (1997) 'Risk mitigation in large-scale systems: lessons from high reliability organizations’. California Management Review. 39(4). pp. 152-162.

Green, R. and M. Cubrinovski (2010) Geotechnical Reconnaissance of the 2010 Darfield (New Zealand) Earthquake. First edition. GEER Association, Christchurch.

Haynes, G.W., R. Walker, B.R. Rowe, and G.-S. Hong (1999) 'The intermingling of business and family finances in family-owned businesses’. Family Business Review. 12(3). pp. 225-239.

Huston, L. and N. Sakkab (2006) ‘Connect and develop: inside Procter and Gamble’s new model for innovation'. Harvard Business Review. 84(3). p. 58-66.

Ingham, J. and M. Griffith (2010) Performance of Unreinforced Masonry Buildings during the 2010 Darfield (Christchurch, NZ) Earthquake. NZSEE (New Zealand Society for Earthquake Engineering) Clearinghouse, Christchurch.

Kroll, C., J. Landis, Q. Shen, and S. Stryker (1991) Economic Impacts of the Loma Prieta Earthquake: A Focus on Small Business. Working Paper No. 91. University of California Transportation Center, University of California, Berkeley, CA.

Labour and Immigration Research Centre (2011) A Changing Landscape: The Impact of the Earthquakes on Christchurch Workplaces. Labour and Immigration Research Centre, Wellington.

McManus, S. (2008) Organisational Resilience in New Zealand. University of Canterbury, Christchurch. New Zealand Treasury (2010) ‘Analysis: Monthly economic indicators September 2010’. New Zealand Treasury, Wellington. 
Persson, H. (2004) 'The survival and growth of new establishments in Sweden, 1987-1995'. Small Business Economics. 23(5). pp. 423-440.

Pettinga, J., M.D. Yetton, R.J. Van Dissen, and G. Downes (2001) 'Earthquake source identification and characterisation for the Canterbury Region, South Island, New Zealand'. Bulletin of the New Zealand Society for Earthquake Engineering. 34(4). pp. 282-317.

Pronovost, P.J. et al. (2006) ‘Creating high reliability in health care organizations’. Health Services Research. 41(4Pt.2). pp. 1599-1617.

Quigley, M. et al. (2011) 'Surface rupture during the 2010 Mw 7.1 Darfield (Canterbury) earthquake: implications for fault rupture dynamics and seismic-hazard analysis’. Geology. 40(1). pp. 55-58.

Rhodes, T., B. Willis, and W. Smith (2003) Farm Adjustment and Restructuring in the North Island Hill Country. MAF Technical Paper. Vol. 2. Citeseer, Wellington.

Rose, A. et al. (2007) 'Benefit-cost analysis of FEMA hazard mitigation grants’. Natural Hazards. 8(4). pp. 97-111.

Smith, M. and R. Krannich (2001) 'Growth, decline, stability, and disruption: a longitudinal analysis of social well-being in four western rural communities'. Rural Sociology. 66(3). pp. 425-450.

Stephenson, A. (2010) Benchmarking the Resilience of Organisations. University of Canterbury, Christchurch.

Stephenson, A., E. Seville, J. Vargo, and D. Roger (2010) Benchmark Resilience: A Study of the Resilience of Organisations in the Auckland Region. Resilient Organisations Research Report 2010/03b. Resilient Organisations, Christchurch.

Stevenson, J., E. Seville, H. Kachali, and J. Vargo (2011) Post-Disaster Organisational Recovery in a Central Business District Context. Resilient Organisations Research Report 2011/03. Resilient Organisations, Christchurch.

Tierney, K.J. (1997) 'Business impacts of the Northridge earthquake'. Journal of Contingencies and Crisis Management. 5(2). pp. 87-97.

Tierney, K.J. and J. Nigg (1995) Business Vulnerability to Disaster-related Lifeline Disruption. Disaster Research Center, University of Delaware, Newark, DE.

Tonkin and Taylor Limited (2010) Darfield Earthquake 4 September 2010: Geotechnical Land Damage Assessment and Reinstatement Report. Tonkin and Taylor Limited, Christchurch.

Vargo, J. and E. Seville (2011) ‘Crisis strategic planning for SMEs: finding the silver lining’. International Journal of Production Research. 49(18). pp. 5619-5635.

Wasileski, G., H. Rodriguez, and W. Diaz (2011) 'Business closure and relocation: a comparative analysis of the Loma Prieta earthquake and Hurricane Andrew’. Disasters. 35(1). pp. 102-129.

Webb, G.R., K.J. Tierney, and J.M. Dahlhamer (1999) Businesses and Disasters: Empirical Patterns and Unanswered Questions. Preliminary Paper No. 281. Disaster Research Center, University of Delaware, Newark, DE. 
Webb, G.R., K.J. Tierney, and J.M. Dahlhamer (2002) 'Predicting long-term business recovery from disaster: a comparison of the Loma Prieta earthquake and Hurricane Andrew'. Global Environmental Change Part B: Environmental Hazards. 4(2-3). pp. 45-58.

Welch, D. (2008) 'New Zealand business demography statistics (structural): at February 2007’. http://www.stats.govt.nz/browse_for_stats/businesses/business_characteristics/nz-businessdemography-statistics-info-releases.aspx (accessed on 22 October 2013).

Winter, M. and M. Fitzgerald (1993) 'Continuing the family-owned home-based business: evidence from a panel study’. Family Business Review. 6(4). pp. 417-426.

Woods, D.D. and J. Wreathall (2008) 'Stress-strain plots as a basis for assessing system resilience'. In E. Hollnagel, C.P. Nemeth, and S. Dekker (eds.) Resilience Engineering Perspectives: Remaining Sensitive to the Possibility of Failure. Ashgate, Aldershot. pp. 145-161.

Zhang, Y., M. Lindell, and C. Prater (2009) 'Vulnerability of community businesses to environmental disasters’. Disasters. 33(1). pp. 38-57. 